\title{
Development of future foreign language teachers' information literacy and digital skills in Ukrainian context
}

\author{
Tetiana Konovalenko*, and Yuliia Nadolska \\ Bogdan Khmelnitsky Melitopol State Pedagogical University, Department of Methodology of Teaching Germanic Languages, Melitopol, \\ Ukraine, 72300
}

\begin{abstract}
The aims of this paper are to share the results of the action research of the future foreign language teachers' information literacy and digital skills development and to demonstrate the opportunities for their development while pre-service teacher training process in the course of Methodology of foreign language teaching and practical course of foreign language. The article discusses the skills of information and communication technologies use in learning and teaching as an important component of future teachers' training and a contribution to the sustainable development of the country. The projects which influenced the action research elaborating are described. A short overview of relevant experience within the studied issue is presented. The procedure of action research is described, the examples from author-tailored course are given.
\end{abstract}

\section{Introduction}

Modern Ukrainian society moves ahead rapidly and requires immediate actions from the system of higher education as it is responsible for the professional training of highly-qualified specialists in various branches. However, the initial responsibility is surely on secondary education which prepares the basis for the further professional journey. Thus, a teacher is considered to be a rather important person in the development of the society.

While the students obtain their higher education, the reality changes and they take risk to acquire the out-ofdate model of professional competence. It is a challenge to find the way out of this situation. Future teachers can and should be taught to develop their own professional thinking, awareness and skills.

In the Decree of the President of Ukraine "On the Aims of Sustainable Development of Ukraine within the Period till 2030", it is pointed that to promote the national interests of our country, the diverse and equitable quality education and opportunities for lifelong learning should be provided for all Ukrainian people [1].

Information literacy and digital safety are among the most important 21 st century skills without which the modern teacher will not be able to provide effective teaching and cater for students' learning under the conditions of continuing innovation and modernisation of education irrespectively of its level (pre-school, primary, secondary, high school, vocational, pre-higher and higher education) or type (formal, informal).

It is stated in the United Nations Agenda for Sustainable Development that "the spread of information and communications technology and global interconnectedness has great potential to accelerate human progress, to bridge the digital divide and to develop knowledge societies" [2]. In section b of goal 4 prescribing to ensure inclusive and equitable quality education and promote lifelong learning opportunities for all, it is emphasised that the actions will be aimed at substantial expanding globally "the number of scholarships available to developing countries, ...for enrolment in higher education, including vocational training and information and communications technology, technical, engineering and scientific programmes, in developed countries and other developing countries" [2]. The necessity of enhancing the use of information and communications technology is focused in the document.

The role of education in sustainable development as the key issue is emphasised in United Nations documents and is presented in reflections on "A Decade of Progress on Education for Sustainable Development": "Students should be supported in acquiring (key) competencies, which help lead to a sustainable, future-oriented society. These include skills for creative and critical thinking, oral and written communication, collaboration and cooperation, conflict management, decision-making, problem solving and planning, using Information and Computer Technology (ICT) appropriately, and practical citizenship" [3]. The purpose of this reflective paper is to take into considerations the achievements and pressing challenges of the previous work and research.

The aims of this paper are to reveal the importance of the future foreign language teachers' information literacy and digital skills and to demonstrate the opportunities for their development while pre-service teacher training

\footnotetext{
* Corresponding author: tetiana konovalenko@mdpu.org.ua
} 
process.

\section{Methods}

The methodology of our research is presented with stepby-step procedure of action research.

The action research contained several stages according to Dai-Ling Chen procedure [4]:

- identifying problem of meaning (starting point, kick off, notice, find interesting area, etc.);

- developing questions and examine assumptions (reflect and formulate questions);

- planning (choosing enquiry strategies, ways of gathering data, planning interventions);

- taking action (intervening);

- gathering data (wider evidence);

- analysing data (reflecting on wider evidence, qualitative analyses);

- interpreting data (assessing impact on teaching and learning);

- reporting (formulating recommendations);

- taking action (wider scale intervention).

The issues of future foreign language teachers' preservice training are rather well-studied, though there still are the aspects which have not been paid enough attention. Such an issue is the one associated with skills of handling with information and communication technologies. So, we have studied Ukrainian and foreign experience of the future foreign language teachers' information literacy and digital safety skills.

The next stage of our research was the study which helped us to collect the data about university students' and school teachers' confidence in using information and communication technologies in the classroom.

This study confirmed that it is important to answer the research question: What are the most effective ways to train information-literate and digital-safety aware teacher of foreign language?

While planning the future foreign language teachers' information literacy and digital skills development we took into consideration the results of the survey, trying to cater for all key competences necessary in teaching and organising students' learning.

Taking action, i.e. implementing the tailor-made course "Information and Communication Technologies in Learning and Teaching", which was a separate unit within the course "Methodology of English Language Teaching", was realised simultaneously with finding the evidence of the effectiveness of the suggested content, modes of interaction, motivation and outcomes. To prove that the designed course could really enhance the technologies impact in the classroom we analysed and interpreted the data gained in the process of its implementing.

\section{Results and discussions}

The need for changes in the system of Ukrainian higher education launched the projects aimed at its modernisation and quality improvement. As Ukraine tries to be in line with European and world standards, international organisations help it to reform all levels of educational system. Recently the reform of pre-school education has just began, the UK Government and British Good Governance Fund support it; New Ukrainian School Concept is based on "Recommendation of the European Parliament and of the Council of 18 December 2006 on Key Competences for Lifelong Learning" (2006/962/EU); Ministry of Foreign Affairs of Finland supports this reform financially; The Lego Foundation contributes to the development of Ukrainian primary school.

As for higher education it is actively supported with the British Council and the British Embassy, America House, IREX and the US Embassy, Goethe-Institute and the Germany Embassy. For the last five years the most crucial in the sphere of teacher training were two projects implemented by British Council and GoetheInstitute.

Goethe-Institute project "Deutsch Lehren Lernen" [5] presents a series of continuing programme of learning based on innovative didactic approach of action research and corresponds to the world quality standards of teacher training. The project system comprises the integration of methodology of language teaching and foreign language learning as two inseparable components of a future teacher's professional competence.

"Deutsch Lehren Lernen" suggests the tasks on systematic observation and reflection on pedagogical activity by means of German language video-lessons from three continents. As the follow-up activities, the students can participate in one-week on-line course moderated by mentors. On accomplishing the course the students are to do the planning and elaborate their own action research project.

The project activity is based on blended learning and combines traditional language learning with digital learning, i.e. doing on-line tasks, new words and patterns revision and use, virtual collaboration with group-mates, virtual class learning, Adobe Connect webinars for both students and teachers with the system of completed tasks monitoring.

There are such effective learning tools as Page Player-App, E-book, introductory on-line test (Einstufungstest online), media-pack, help-test (Testhelf), application for the work with vocabulary (Vokabeltrainer-App), supplementary on-line materials, bilingual glossary. The advantage of the project course is obvious as it promotes and motivates students' learning and helps teachers to deliver their teaching taking into consideration all challenges of modern education and information and communication technologies development.

The project "New Generation School Teacher" [6] was initiated by British Council Ukraine and the Ministry of Education and Science of Ukraine in 2013. It aimed at introducing change to the initial teacher education system in Ukraine. The project resulted with the PRESETT curriculum in Methodology and the network of Ukrainian universities implementing it and proving its effectiveness. The project outcomes were presented with such learning ones as: 
- Student-teachers' and newly-qualified teachers' English proficiency is improved.

- Their classroom skills and confidence are enhanced.

- Their digital and social media skills are developed.

- On the level of action outcomes the newly-qualified teachers:

- teach more effectively and confidently;

- engage with colleagues;

- join networks and meet colleagues overseas;

- can integrate ICT in/outside the classroom;

- are committed to CPD.

As it can be seen the ICT skills were paid special attention and there was designed a separate unit of the new Methodology course "ICT in Learning and Teaching". Its objectives are to form the students' awareness of the advantages and disadvantages of doing activities on a computer and other electronic devices as opposed to similar paper-based activities; the criteria for evaluating and selecting online resources for language teaching purposes; and to develop their skills to use different software (e.g. MSWord, PowerPoint) for language learning and teaching purposes; make use of social networking sites, blogs, wikis, etc. in language teaching; evaluate the potential of online audio and video for language teaching purposes; assess possible risks of using the Internet with young learners and develop a set of rules for cyber safety; explore current trends in mobile learning and be able to use mobile phones for teaching and learning reference.

The whole project represents the large-scale research which comprised 8 university at its beginning, and 13 universities and colleges within the period of its piloting. Our small-scale research was based in its results but was elaborated on the content prepared and piloted in Bogdan Khmelnitsky Melitopol State pedagogical university only.

Besides of "New Generation School Teacher" project results we used the experience of our participation in the joint project of International Research and Exchanges Board, Academy of Ukrainian Press and Ministry of Education and Science of Ukraine "Learn to Discern: Info-Media Literacy" as its realisation is concerned around integrating info-media focused modules or courses into pre-service teacher training syllabus. In spite of the fact that the project is mostly oriented at the training of teachers of Ukrainian Language and Literature, History and Arts, we have implemented its element in our courses for future teachers of foreign languages.

The amended and modernised curricula of Methodology of Foreign Language Teaching and The First Foreign Language develop teacher profile specialty-based competences as well as critical thinking skills, implement interactive methods of learning and teaching, dialogue modes of interaction, and the ample use of online tools.

While identifying the issue for doing our action research we studied the experience presented in scientific-methodological resources and found out the challenges and opportunities for our learning and teaching context.

The role of information and communication technologies in higher education has been being studied since the very beginning of their appearance and application in this branch. The issue has its diachronic and space aspects, i.e. in different periods we observe the studies of various technologies and the context of national systems of education, types of educational institutions, technical and financial capability, and other numerous factors have an impact on the ICT use and their role.

The experience of developing countries demonstrates that the role of ICT for sustainable education has always been considered the potential positively transform the higher education though the accessibility of ICT facilities is still low. Such conclusions were made in 2011 by S. A. Bello and S. Johnson from University of Lagos in Nigeria. Their data were collected from 800 lecturers selected from 16 higher education institutions in the country [7]. The researchers admitted that the problem was associated not only with the availability itself, but with the digital and information illiteracy of teachers.

A year later a similar research was presented by Ajit Mondal and Jayanta Mete, scientists from India, who pointed that "the introduction of ICTs in the higher education has profound implications for the whole education process especially in dealing with key issues of access, equity, management, efficiency, pedagogy and quality" [8]. They assessed the importance of solving the problem as the one meeting the stakeholders' needs and expectations. Thus, these scientists ascertained such benefits of ICT in education to the main stakeholders: "increased access, flexibility of content and delivery, combination of work and education, learner-centred approach, higher-quality of education and new-ways of interaction" for students; "high quality, cost effective professional development in the workplace, upgrading of employee skills, increased productivity, developing of a new learning culture, sharing of costs and of training time with the employees, increased portability of training" for employers" "increase the capacity and cost effectiveness of education and training systems, to reach target groups with limited access to conventional education and training, to support and enhance the quality and relevance of existing educational structures, to ensure the connection of educational institutions and curricula to the emerging networks and information resources, to promote innovation and opportunities for lifelong learning" for governments [8].

It is obviously that the ICT use in higher education provides for both personal professional development and the world's information-digital-literate society. Modern education should be available for all people always and everywhere. That is why "life-long learning has become the driving force to sustain in the contemporary competitive environment. Therefore to strengthen and / or advance this knowledge-driven growth, new technologies, skills and capabilities are needed" [8].

The other scientists' action research reports supplied us with additional evidence that we are on the right way. Such research was elaborated by Beata Lewis Sevcikova 
who integrated information technologies into TEFL training. When she summarised the action research activity she noticed that the students "believed that technology is essential for the future; it enhances learning and teaching, supports collaboration and motivation. They also pointed out some limitations such as IT literacy, the time-consuming nature of technology, and the lack of access to free internet learning/teaching resources" [9].

We used the colleagues' experience as the problems of ICT use in higher education context proved to be similar with many educational institutions from different countries.

The overview of the issue helped with the starting point of our research and finding the relevant area. Still we had to specify the narrow aspects for elaborating and implementing. This was a cause for doing the survey. Our respondents were university students and school teachers. The questions asked were about their attitude to the use of ICT in class, their confidence in this practice, and their skills in handling with cyber well-being, websites and learning platforms choice, online resources use, social networking, blogs, wikis application, flipped teaching, proper use of various devices such as mobile phones, tablets, laptops, interactive whiteboards. There were 200 students and 30 teachers who took part in the survey.

The so-called "digital divide" revealed itself in the process of survey as only two of teachers (6,7 \%) answered that they are completely confident as for ICT use in classroom. Completely confident students were $49 \%$. Though, the questions about cyber well-being, websites and learning platforms choice, blogs and wikis application, understanding of flipped teaching demonstrated that there were some gaps in their information literacy and digital safety skills.

For teachers who took part in our survey we prepared a series of workshops to help them in ICT application in foreign language classrooms.

For students, on the basis of our baseline study we elaborated the unit "Information and Communication Technology (ICT) in Learning and Teaching English" [10] which was based on blended learning and included the following items:

- Modern learning technologies and their relevance for the educational process.

- Cyber well-being: keeping children safe on the Internet.

- Selecting and evaluating websites for teaching and learning purposes.

- The use of learning platforms (e.g. Moodle) for teaching purposes.

- Using online audio and video resources for language learning and teaching purposes.

- Exploration of opportunities offered by social networking sites, blogs, wikis to language learning and teaching.

- The notion of a 'flipped' classroom and its benefits; traditional vs. flipped teaching.

- The main uses of IWBs (interactive whiteboards). and their benefits as opposed to traditional whiteboards.
- Exploration of opportunities offered by mobile devices (e.g. smartphone) in language learning.

- The use of different software and online tools for teaching and learning purposes.

- Power Point making rules.

- Effective ways of information search, finding the primary sources. Accumulating and generalising the information.

- The notions of copyright and plagiarism. Following the copyright. How to avoid plagiarism.

- Teacher's skills in photo, logo, symbols, posters, emoticons, memes, infographics use.

There were no traditional lectures within delivering this unit. The main modes of interaction were presented with games, jigsaw learning, buzz groups, socratic technique, role play, workshop, simulation, cross-over groups, guided reading, lecturette, brainstorming, speaking corners and others. Of all methodology units this one was of the greatest interest for students and positively influenced their motivation to learning. It was confirmed at each session which ended with taking students' feedback.

Each session began with studying the experience on the topic of it. Starting where the students are helped us to choose between possible variables and contributed to making the unit content and methodology of its deliverance more flexible.

Here there are some examples of organising the learning within the unit. In the session devoted to cyberwell-being, after getting acquainted with its principles, watching several videos and brainstorming all ideas about safe use of the Internet, the students make a list of rules for communicating in the world web. They work in groups and find the examples to each rule from the Internet. Each group creates a document on a Google Drive and then works with all lists created by other groups. They add other suggestions or comment on other groups' products. After discussing the rules of netiquette, one student takes a responsibility to make an accumulated netiquette code and shares it with all students.

One more example of work in teams is presented with evaluating the sites. Before doing this evaluation, the students learn the following criteria essence:
1. Audience
2. Credibility
3. Accuracy
4. Objectivity
5. Coverage
6. Currency
7. Aesthetic or visual appeal
8. Navigation
9. Accessibility

After that their teams work with different educational websites and evaluate the possibilities for their use in the narrow context, i.e. they are informed on the age of learners and their level of English.

When one team presents their findings the representatives of other ones ask questions and give comments. The activity is summarised with formulating tips for the work with websites. 
The work with online courses was a little more timeconsuming for students as they had to begin some courses (according to their learning interests) on various learning platforms such as futurelearn.com or openlearning.com. After diving into their courses and getting access to all platform tools, students analysed the content management, curriculum mapping and planning, ways of communication and management of the platform. On the stage of discussing the platforms the students are asked to reflect on their possible moderating such courses, strengths and weaknesses of them.

The use of social networks in learning and teaching arouse the most interest of students. This topic was studied with simultaneous revision of keeping children safe on the Internet. The students suggested the ways of possible algorithms of social media use for educational purposes. This way of ICT use was studied in microteaching as students prepared 1-2 activities for their group-mates playing the roles of school students. Through the prepared activities a student-teacher taught English or German to his/her school students. After each microteaching there was a feedback session aimed at finding positive features and methodological mistakes so that avoid them in real classroom.

Especially valuable for students was the work with wikis and blogs as they promote online writing which is rather important for teachers-philologists. In this case we asked students to create their own blogs. They worked in small groups and had one task per a group. To make use of the task they created the blogs of newly-qualified teachers so that they could use them while having their school experience (practice).

All above-mentioned examples were used in methodology class, though sometimes we applied activities of the same typology in our language classes. We give just one example of a task in the class where German is taught as the second foreign language.

So, the students got a set of QR-codes (Fig. 1) with the help of which they had to find the endings of the statements beginnings of which were given. Then they had to match parts of statements according to the logic approach:

1. ein Buch

2. Insektenspray

3. Sonnencreme

4. eine Taschenlampe

5. Aspirintabletten

6. ein Handy

7. einen Laptop

8. eine Digitalkamera

9. viel Geld

10. eine Kopie vom Reisepass

11. den Führerschein

12. Ohropax

Sometimes students matched the equal numbers of parts, but from time to time there were excessive parts which were not necessary.

In practical language classes especially often were used mobile phones applications as they helped to work with vocabulary and grammar (visualising, training, revision, test control), listening. Writing skills were monitored on the level of messaging. Still for larger pieces of writing we used standard e-mail writing which helped students to learn to write various types of letters. Before writing such letters, they searched the information necessary for that very kind of a letter.
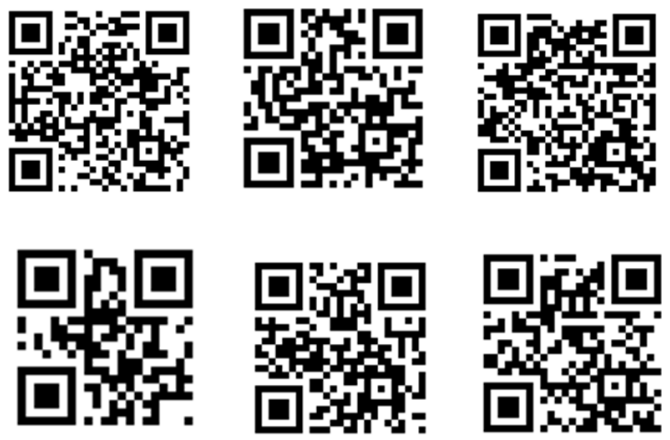

Fig. 1. QR-codes puzzle.

While gathering data on our action research we looked for wider evidence of the unit effectiveness. That is why the same survey was conducted once more. It confirmed that most of students $(87 \%)$ began to feel more confident as for ICT use in class. Besides, they were acquainted with a wide range of software, online tools, applications and other methodologically valuable ICT items.

The ICT use in learning and teaching unit was a very dynamic and useful for future teachers. Its importance and relevance were confirmed by students and teachers. It is the call of the time to make the classroom blended and to transfer a part of learning to virtual reality which so important for "digital native" school students. Besides, modern university students are ready to implement the ICT innovations.

The students had a good opportunity to train in using ICT in hands-on activities when they had their school experience (practice). So, their reflective journals they wrote while practice contained the same feedback as in the end of each methodology session: the ICT is a powerful methodological tool and the factor which favours learning and teaching stay effective.

Still the application of ICT in both teacher training and those teachers' future professional activity can be considered unlimited as the technology is rapidly developing and changing the world around us as well as the educational opportunities. Virtual reality contains the enormous potential for improving the quality of learning and teaching foreign languages. This issue have been studied by S. V. Symonenko, N. Zaitseva, V. Osadchyi, K. Osadcha and E. Shmeltser who emphasized that "the practice of immersion into virtual environment in foreign language learning will enable students to feel themselves an integral part of the professionally oriented situation which is designed specifically to prepare the course participants for communication within" [11]. This team of researchers point that virtual reality tasks help students to get used to "psychological challenges and apply existing speaking skills in a foreign language", "encourage spontaneity" and increases students" motivation to "achieve better results in a training course" 
[11]. Virtual reality is especially valuable for teaching languages in the conditions of natural language speech environment. Besides of demonstrating "situational models of possible daily life circumstances for foreign language communication" [11], virtual reality-based tasks surely promote the development of future teachers' information literacy and digital skills.

\section{Conclusions}

The results of our action research helped us to prove the importance of the future foreign language teachers' information literacy and digital safety skills development to our students. The prepared materials, chosen ways of teaching, possibility to apply all they got to know demonstrated to future teachers the opportunities for their development while pre-service teacher training process.

The elaborated unit implementing contributed to the development of future teachers' awareness of the advantages and disadvantages of ICT use in the classroom, the criteria for evaluating and selecting online resources and ICT software and applications for language teaching purposes, skills of using various software, social networking sites, blogs, wikis, online tools in language teaching, evaluating the potential of online audio, video and other visuals, assessing possible risks of using the Internet with learners and creating conditions for cyber safety, using various electronic devices justified for achieving educational aims.

Their Methodology and language classes supplied future teachers with the set of professionally valuable awareness and skills which will encourage them to follow-up their journey from newly-qualified teacher to an experienced one who will be information literate and ready to create digitally-safe learning environment. This is one of the conditions for sustainable development of our country.

There are still a lot of issues waiting for further study and finding solutions. For future teachers of foreign languages it would be a great opportunity to learn handling with the virtual reality with specific purposes in their professional area. Ability of producing digital content is one more urgent need for teachers of any subject. It is important for all modern teachers to become competent in information and communication technologies use as they are to accelerate human progress and work for its sustainable future by means of ensuring inclusive and equitable quality education for the youth.

\section{References}

1. Ukaz Prezidenta Ukrainy "Pro tsili stalogo rozvytku ukrainy na period do 2030 roku" (The Decree by the President of Ukraine "On the aims of sustainable development of Ukraine within the period till 2030" (Kyiv, 2019)

2. Transforming our world: the 2030 agenda for sustainable development (United Nations), https://sustainabledevelopment.un.org/index.php?pag $\mathrm{e}=$ view \&type $=111 \& \mathrm{nr}=8496 \& \mathrm{menu}=35$. Accessed 15 Feb 2020

3. G. Michelsen, S. Burandt, A decade of progress on education for sustainable development reflections from the UNESCO Chairs Programme (2017)

4. Dai-Ling Chen, Developing critical thinking through problem-based learning. An action research for a class of media literacy, Dissertation, Durham University, 2015

5. Deutsch Lehren Lernen (2019), https://www.goethe.de/ins/ua/de/spr/unt/for/gia/dll.ht ml. Accessed 10 Feb 2020

6. Project New Generation School Teachers (2019), http://www.britishcouncil.org.ua/en/teach/projects/pr esett. Accessed 10 Feb 2020

7. S.A. Bello, S. Johnson, Role of ICT in managing higher education for sustainable development. Makerere Journal of Higher Education 3(1) (2011)

8. A. Mondal, J. Mete, ICT in Higher Education: Opportunities and Challenges. Bhatter College Journal of Multidisciplinary Studies II (2012), http://bcjms.bhattercollege.ac.in/ict-in-highereducation-opportunities-and-challenges/. Accessed 15 Feb 2020

9. B.L. Sevcikova, Integrating technology into TEFL training, in Using action research to explore technology in language teaching: international perspectives (Aston University, Australia, 2016), p. 45

10. O. Goncharova, T. Konovalenko, Metodychna pidgotovka maibutniogo vchytelia do navchannia angliiskoi movy (Future teacher's training for teaching English language) (Melitopol, 2019), pp. $169-220$

11. S.V. Symonenko, N.V. Zaitseva, V.V. Osadchyi, K.P. Osadcha, E.O. Shmeltser, Virtual reality in foreign language training at higher educational institutions. CEUR Workshop Proceedings 2547, 3749 (2020) 